\title{
Pemberian Rempah dan Suplemen Organik Cair terhadap Performans Ternak Puyuh
}

\author{
Alpia Sahupala ${ }^{1}$, Maria Herawati ${ }^{1}$, Nurtania Sudarmi ${ }^{1 *}$ \\ ${ }^{1}$ Program Studi Penyuluhan Peternakan dan Kesejahteraan Hewan, Politeknik Pembangunan \\ Pertanian Manokwari \\ *Corresponding author: nurtania@pertanian.go.id
}

\begin{abstract}
Abstrak
Banyak keuntugan yang didapat dari penggunaan rempah selain untuk manusia, rempah juga berguna bagi ternak mulai dari peningkatan daya tahan tubuh dan stress, hingga menekan tingkat kematian semasa pemeliharaan. Pemanfaatan rempah diyakini membuat kolestrol jahat dalam darah dan daging ternak berkurang. Peternak di Manokwari, Papua Barat umumnya menggunakan tanaman rempah untuk pencegahan penyakit maupun meningkatkan performa ternak. Penelitan ini bertujuan untuk mengetahui performa ternak puyuh yang diberikan rempah dengan suplemen organik cair dalam air minum ternak. Percobaan menggunakan 150 ekor burung puyuh dengan perbandingan 30 ekor jantan dan 120 ekor betina. Percobaan menggunakan Uji T untuk melihat performans ternak puyuh dengan peubah yang diamati meliputi konsumsi pakan, konsumsi air minum dan produksi telur. Rataan pemberian rempah dengan suplemen organik cair sebagai air minum pada ternak puyuh berpengaruh signifikan terhadap peningkatan konsumsi pakan serta penurunan konsumsi air minum dan produksi telur. Hasil penelitian menunjukkan rempah dengan suplemen organik cair dapat diberikan sebagai minum ternak ternak puyuh tanpa menggangu proses metabolisme.
\end{abstract}

Kata kunci: Burung puyuh, Performans, Rempah

\begin{abstract}
Many advantages are obtained from the use of spices other than for humans, spices are also useful for livestock ranging from increasing body resistance and stress, to reducing mortality rates during maintenance. The use of spices is believed to reduce bad cholesterol in the blood and meat of livestock. Farmers in Manokwari, West Papua generally use spice plants to prevent disease and improve livestock performance. This study aims to determine the performance of quail who are given spices with liquid organic supplements in livestock drinking water. The experiment used 150 quails with a ratio of 30 males and 120 females. The experiment used the T test to see the performance of quail with the observed variables including Feed Consumption, Drinking Water Consumption and Egg Production. The average provision of spices with liquid organic supplements as drinking water in quail had a significant effect on increasing feed consumption and decreasing drinking water consumption and egg production. The results showed that spices with liquid organic supplements could be given as drinking to quail livestock without disturbing the metabolic process.
\end{abstract}

Keywords: Performance, Spices, Quail 
Prosiding Seminar Nasional Pembangunan dan Pendidikan Vokasi Pertanian

Politeknik Pembangunan Pertanian Manokwari, 31 Juli 2021

e ISSN : 2774-1982

DOI : https://doi.org/10.47687/snppvp.v2i1.188

\section{PENDAHULUAN}

Komoditi unggas yang semakin populer di masyarakat saat ini adalah Burung Puyuh (Coturnix japonica). Hal ini terbukti dengan meningkatnya populasi ternak puyuh di Papua Barat yang tercatat pada tahun 2018 berjumlah 2.100 ekor kemudian mengalami peningkatan pada tahun 2019 menjadi 2.300 ekor.

Burung Puyuh (Coturnix japonica) mempunyai potensi yang besar untuk dikembangkan ternak ini memiliki beberapa kelebihan seperti berat telur yang berkisar 911 gram yang mengandung banyak protein, daging yang lezat serta tidak memerlukan tempat yang luas dengan modal yang relatif kecil. Walaupun memiliki beberapa kelebihan teknik pemeliharaan ternak puyuh pun tidak berbeda dengan ternak yang lain faktor lingkungan harus diperhatikan dan disesuaikan dengan kebutuhannya. Perubahan lingkungan akan menyebabkan puyuh mengalami strees yang akan mempengaruhi produktifitas dari puyuh.

Rempah memiliki fungsi sebagai penambah nafsu makan, menghilangkan stress, mencegah penyakit dan menghangatkan badan sehingga hal ini dapat mengatasi permasalahan yang disebabkan oleh perubahan suhu maupun pakan sehingga nafsu makan tetap tinggi dan produktifitas dari burung puyuh tetap stabil maupun meningkat. Rempah yang digunakan dihasilkan dari beberapa bahan bahan rempah seperti jahe merah, lengkuas, bawang merah, bawang putih, temulawak, kencur, kunyit, serei, daun mayana, daun sirih, dan gula merah yang kemudian di ekstrak dan di campur ke dalam air minum ternak.

Banyak sekali keuntugan yang didapat dari penggunaan rempah selain untuk manusia, rempah juga berguna bagi ternak mulai dari peningkatan daya tahan tubuh dan stress, hingga menekan tingkat kematian semasa pemeliharaan. Pemanfaatan rempah diyakini membuat kolestrol jahat dalam darah dan daging ternak berkurang. Peternak di Manokwari, Papua Barat umumnya menggunakan tanaman rempah untuk pencegahan penyakit maupun meningkatkan performa ternak.

Kandungan dari setiap bahan yang digunakan dalam rempah memiliki aroma yang dapat merangsang kelenjar pencernaan baik untuk membangkitkan nafsu makan maupun pencernaan. Oleh karena itu, perlu kajian bagaimana pengaruh pemberian rempah terhadap konsumsi pakan, konsumsi air minum, dan produksi telur. 
Prosiding Seminar Nasional Pembangunan dan Pendidikan Vokasi Pertanian

Politeknik Pembangunan Pertanian Manokwari, 31 Juli 2021

e ISSN : 2774-1982

DOI : https://doi.org/10.47687/snppvp.v2i1.188

\section{METODE}

Penelitian ini dilaksanakan di Tefa ternak Puyuh Kampus I Politeknik Pembangunan Pertanian Manokwari, dari tanggal 7 Juni 2021 sampai 21 Juni 2021. Pada penelitian ini digunakan 150 ekor ternak puyuh yang terdiri dari puyuh jantan 30 ekor dan betina 120 ekor dengan 2 perlakuan yaitu pemberian air putih dan rempah. Penelitian ini dilakukan di Tefa Ternak Puyuh Kampus I Polbangtan Manokwari

\section{Tahap Penelitian}

1. Penyiapan Materi

2. Pengamatan Performans Pertumbuhan

\section{Penyiapan materi penelitian}

Untuk mendapatkan materi penelitian digunakan 75 ekor puyuh dengan umur \pm 1 tahun yang terdiri dari 15 ekor jantan dan 60 ekor betina dipelihara dengan perbandingan jantan betina $1: 4$ dengan setiap kandang terdiri dari 5 ekor sehingga terdapat 15 kandang.

Variabel yang diamati adalah komsumsi pakan, komsumsi minum dan produktivitas telur. Analisis data untuk melihat perbedaan pemberian air putih dan rempah data yang diperoleh dianalisis dengan uji $\mathrm{T}$.

\section{HASIL DAN PEMBAHASAN}

Rataan kemampuan puyuh mengkonsumsi air minum, ransum dan produksi telur dengan penelitian selama 2 minggu dengan 15 ulangan masing-masing ulangan terdiri dari 1 jantan dan 4 betina dalam setiap kandang. Pemberian rempah dan suplemen organik cair berpengaruh signifikan.

Tabel 1. Rataan komsumsi air minum, ransum dan produksi telur puyuh selama penelitian.

\begin{tabular}{lll}
\multirow{2}{*}{\multicolumn{1}{c}{ Variabel }} & \multicolumn{2}{c}{ Perlakuan } \\
\cline { 2 - 3 } & \multicolumn{1}{c}{ Air putih } & \multicolumn{1}{c}{ Rempah } \\
\hline Komsumsi Air Minum & $135.35 \pm 16.48$ & $95.48 \pm 15.72$ \\
Komsumsi Pakan & $23.06 \pm 2.37$ & $23.1 \pm 1,88$ \\
Produksi Telur & $0.60 \pm 0,14$ & $0,57 \pm 0,12$ \\
\hline
\end{tabular}

\section{Konsumsi Air Minum}

Pemberian rempah dan suplemen organik cair berpengaruh signifikan. Rataan konsumsi air minum pada penelitian ini berkisar antara $95.48-135.35 \mathrm{ml} / \mathrm{ekor} / \mathrm{hari}$. Nilai konsumsi air minum ini lebih tinggi dari hasil penelitian Widyastuti dkk. (2014) yang menyebutkan konsumsi air minum burung puyuh berkisar 43 - $65 \mathrm{ml} / \mathrm{ekor} / \mathrm{hari}$ 
Prosiding Seminar Nasional Pembangunan dan Pendidikan Vokasi Pertanian

Politeknik Pembangunan Pertanian Manokwari, 31 Juli 2021

e ISSN : 2774-1982

DOI : https://doi.org/10.47687/snppvp.v2i1.188

Konsumsi air minum pada penelitian ini berpengaruh signifikan. Hal ini dikarenakan rempah yang diberikan memiliki warna coklat kekuningan yang mempengaruhi palatibilitas ternak, karena unggas lebih respon terhadap indra penglihatan dari pada perasa.



Gambar 1. Konsumsi air minum

\section{Konsumsi Pakan}

Pemberian rempah dan suplemen organik cair berpengaruh signifikan. Rataan Konsumsi pakan burung puyuh pada penelitian ini berkisar antara $23.06-23.1 \mathrm{~g} / \mathrm{ekor} / \mathrm{hari}$. Nilai konsumsi pakan ini ini sesuai dengan standar yaitu $21-25$ g/ekor/hari. Hal ini tidak jauh berbeda dengan penelitian Andari dkk., (2018) yaitu 21,37 - 21,57 g/ekor/hari.

Konsumsi pakan pada penelitian ini berpengaruh signifikan. Natamijaya (2005) menyatakan bahwa minyak atsiri dan kurkumin sebagai zat aktif dalam kunyit dapat mempercepat pengosongan isi lambung sehingga meningkatkan nafsu makan dan memperlancar proses pengeluaran empedu.

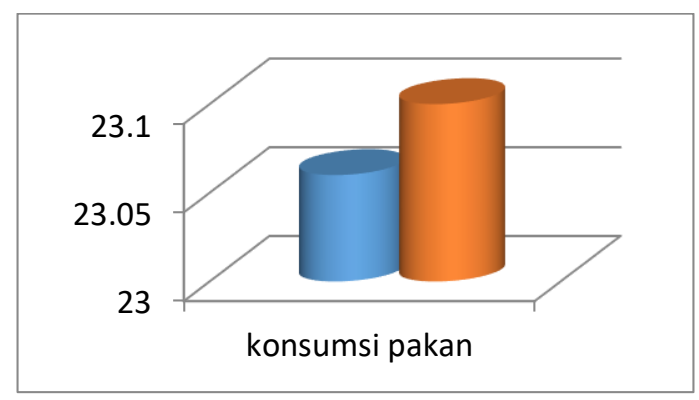

Gambar 2. Konsumsi pakan

\section{Produksi Telur}

Pemberian rempah dan suplemen organik cair berpengaruh signifikan. Rataan produksi telur pada penelitian ini berkisar $0,57-0,60$ butir/ekor/hari. Nilai produksi telur ini hampir sesuai dengan standar yaitu 1 butir/ekor/hari. 
Prosiding Seminar Nasional Pembangunan dan Pendidikan Vokasi Pertanian Politeknik Pembangunan Pertanian Manokwari, 31 Juli 2021

e ISSN : 2774-1982

DOI : https://doi.org/10.47687/snppvp.v2i1.188



Gambar 3. Produksi unggas

Produksi telur pada penelitian ini menunjukan perbedaan yang signifikan diduga pemberian rempah yang mengandung zat anti nutrisi menghambat penyerapan nutrisi dalam tubuh ternak yang mengakibatkan turunnya produksi telur. Di sisi lain umur burung puyuh yang sudah satu tahun, tidak lagi berada dipuncak produksi telur.

\section{KESIMPULAN DAN SARAN}

Pemberian rempah dan suplemen organik cair dapat meningkatkan konsumsi pakan. Selain itu pemberian rempah dan suplemen organik cair belum dapat meningkatkan konsumsi air minum serta produksi telur.

\section{DAFTAR PUSTAKA}

Abidin, Z. (2012). Meningkatkan Produktivitas Puyuh Si Kecil yang Penuh Potensi. Agromedia Pustaka, Jakarta.

Andari, A., Enisa, E. N., Wulandari, R. F., \& Suci, D. M. (2018). Efek suplementasi "Jamu Rempah" pada puyuh (Coturnix coturnix japonica) terhadap performa dan kadar kolesterol telur. Jurnal Ilmu Nutrisi dan Teknologi Pakan, 16(2) : 34-41.

Natamijaya, A.G. (2005). Karakteristik penampilan pola warna bilu, kulit,sisik, dan paruh ayam pelung di garut dan ayam sentul di Ciamis. Buletin Plasma Nutfah. 10(1): 1 -10.

National Research Council (NRC). (1994). Nutrient Requirement of Poultry, 9th Revised Edition. National Academy Press, Washington DC.

Suprijatna, E., U. Atmomarsono, \& R. Kartasudjana. 2005. Ilmu Dasar Ternak Unggas. Penebar Swadaya, Jakarta.

Utami, M.M.D. \& J. Riyanto. (2002). Pengaruh Pemberian Pakan Dengan Metode Pemuasan Terhadap Kinerja Karkas Puyuh. Bulletin Peternakan, 26(1): 13-19

Tini, W., N.S. Asmaniya, \& A. Napirah. (2020). Pemberian Rempah (Jahe, Kunyit, dan Temulawak) terhadap Performa Produksi Telur Burung Puyuh (Corturnix cortunix japonica). 22(2): 242-248.

Wahyuri, M., E. Elfawati, \& Rahmadani. (2014). Manajemen Teknis Produksi Peternakan Puyuh (Studi Kasus Di Peternakan Masagena Kecamatan Tenayan Raya). Jurnal Peternakan, 11(1): 8-21. 
Prosiding Seminar Nasional Pembangunan dan Pendidikan Vokasi Pertanian

Politeknik Pembangunan Pertanian Manokwari, 31 Juli 2021

e ISSN : 2774-1982

DOI : https://doi.org/10.47687/snppvp.v2i1.188

Widyastuti, M., M. Siti \& S. Tyas. (2014). Pertumbuhan Puyuh (Coturnix coturnix japonica) Setelah Pemberian Tepung Kunyit (Curcuma longa L.) pada Pakan. Buletin Anatomi dan Fisiologi, 12(2): 12-20. 